\title{
NESTED AND OVERLAPPING REGIMES IN THE TRANSATLANTIC BANANA TRADE DisPUTE
}

Karen J. Alter

Associate Professor of Political Science

Northwestern University

601 University Pl

Evanston, IL 60201

(847) 491-4842

kalter@northwestern.edu

depot.northwestern.edu/kal438/public_html/index.html
Sophie Meunier

WWS Research Associate

Princeton University

Bendheim 018

Princeton, NJ 08544

(609) 258-4863

smeunier@princeton.edu

www.princeton.edu/ smeunier

An earlier version of this paper was presented at the Conference of Europeanists, March 11-13, 2004, Chicago and at the American Political Science Association Conference, September 2-5 2004, Chicago. We wish to thank Christina Davis, Brian Hanson, Robert Keohane, Andrew Moravcsik, Kenneth Oye, Elliot Posner, Mark Rhinard, Alberta Sbragia, Gregory Shaffer, and Daniel Tarullo for comments. We also wish to thank Cyrus Friedheim of Chiquita and JeanFrancois Brakeland, Aldo Longo and Alberto Volpato at the European Union Commission. We deeply appreciate their help in sorting through the politics of the banana dispute, and freely acknowledge that the interpretation of the motives of actors involved is our own. 


\title{
NESTED AND OVERLAPPING REGIMES
}

\section{IN THE Transatlantic BanANa Trade DispUTE}

$1 / 6 / 05$

\begin{abstract}
The decade long trans-Atlantic banana dispute was not a traditional trade conflict stemming from antagonistic producers' interests. Instead, this article argues that the banana dispute is one of the most complex illustrations of the legal and political difficulties created by the nesting and overlapping of international institutions and commitments. The contested Europe-wide banana policy was an artifact of nesting --the fruit of efforts to reconcile the single market with Lomé obligations which then ran afoul of WTO rules. Using counter-factual analysis, this article explores how the nesting of international commitments contributed to creating the dispute, provided forum shopping opportunities which themselves complicated the options of decisionmakers, and hindered resolution of what would otherwise be a pretty straightforward trade dispute. We then draw out implications from this case for the EU, an institution increasingly nested within multilateral mechanisms, and for the issue of the nesting of international institutions in general.
\end{abstract}

Keywords: bananas; European Union; institutions; nesting; trade; WTO.

Word Count 9456 


\section{Introduction}

Advanced industrial democracies belong to a plethora of international institutions. Either individually or collectively, they are members of universal organizations (UN agencies), regional blocs (e.g. EU, NAFTA, ASEAN) and issue-specific institutions (e.g. WTO, NATO, OECD, WHO). These international institutions can be nested within each other or overlap with each other, sometimes leading to conflicting commitments for their member states. What do countries do when the requirements of membership in one institution contradict those of membership in another institution? How do the nesting and overlapping of international institutions complicate the strategies of national decision-makers? Does the nested and overlapping nature of international commitments in itself generate a distinct kind of politics?

This paper is an inductive exploration of how nesting/overlapping shaped the behavior of decision-makers and created distinct political dynamics in the decade-long international conflict over bananas between the European Union (EU) and the United States. Why this dispute persisted for eleven years is puzzling. The case involved neither significant factual disagreements, nor disagreements over deep-seated values. It did not touch on the Pandora's box of agriculture, a traditional source of transatlantic acrimony. Nor did the US and EU have high stakes in the dispute, since neither of them have significant banana industries. And bananas accounts for only $.03 \%$ of transatlantic trade. In this sense, the banana dispute was not a traditional trade conflict, with antagonistic producers interests on both sides of the fence. In addition, many actors in Europe itself disliked the policy from the beginning. Our analytical focus is on how the nesting of the banana regime- within the EU, the Lomé Convention, and the WTO- contributed to the dispute by constraining decision-makers, thereby making a rather straightforward dispute very difficult to resolve. 
Section I defines nested/overlapping institutions and then develops the argument for how the nesting of institutions creates shifting framing of issues by interest groups and contorted decision-making by legal and political actors. Section II shows how the EC bananas regulation was itself an artifact of nested and overlapping commitments-namely the effort to complete the single market by adopting a single banana import regime while maintaining promises made in the Lomé convention. Producers and importers of Latin dollar bananas found themselves significantly disadvantaged under the new European import system and pursued multi-venue legal, constitutional, and political techniques to challenge the policy within the different nested layers-national legal systems, the EU legal system and the WTO. Section III, uses counterfactual analysis that strips away each of the institutional levels-the Lomé convention, the EU, and the WTO - to reveal how the nesting/overlapping of international commitments shaped decision-making by a variety of actors. The analysis helps explain both the convoluted European banana policy and the difficulty in resolving the banana dispute. In conclusion, we reflect on how generalizable is our focus on nested and overlapping international commitments to understand the politics of decision-making and dispute-resolution in what is an increasingly complex international environment where countries have enmeshed themselves in a variety of biand multi-lateral institutions.

\section{The Nesting and Overlapping of International Commitments}

"Nesting” refers to a situation where regional or issue-specific international institutions are themselves part of multilateral frameworks that involve more states or multiple issues. Institutions are imbricated one within another in concentric circles, like Russian dolls. For 
instance, European states have formed the European Union, which is part of the World Trade Organization.

International institutions need not be nested, however, to overlap in authority. With their multiple institutional commitments, member countries stand at the intersection of independent jurisdictions, like in the overlapping middle part of a Venn Diagram. To continue with the example of trade, European states are members of the EU, but they also belong to the WTO and the ILO, they are part of many bilateral trade agreements with third countries, and some of them are constituting members of the G8. We define “overlapping” as distinct, but related to, nesting. In an overlapping jurisdiction context, a conflict across agreements does not per se mean that one rule is a violation of the other. When institutions are nested, however, conflicting policies of the subsumed regime do constitute a violation of the more encompassing institution. Thus nesting is a subset of the more general problem of overlapping commitments, with the conflicting rules more clearly labeled "violations" of the more encompassing institution. The diagram below captures the difference.

Nested vs. Overlapping institutions

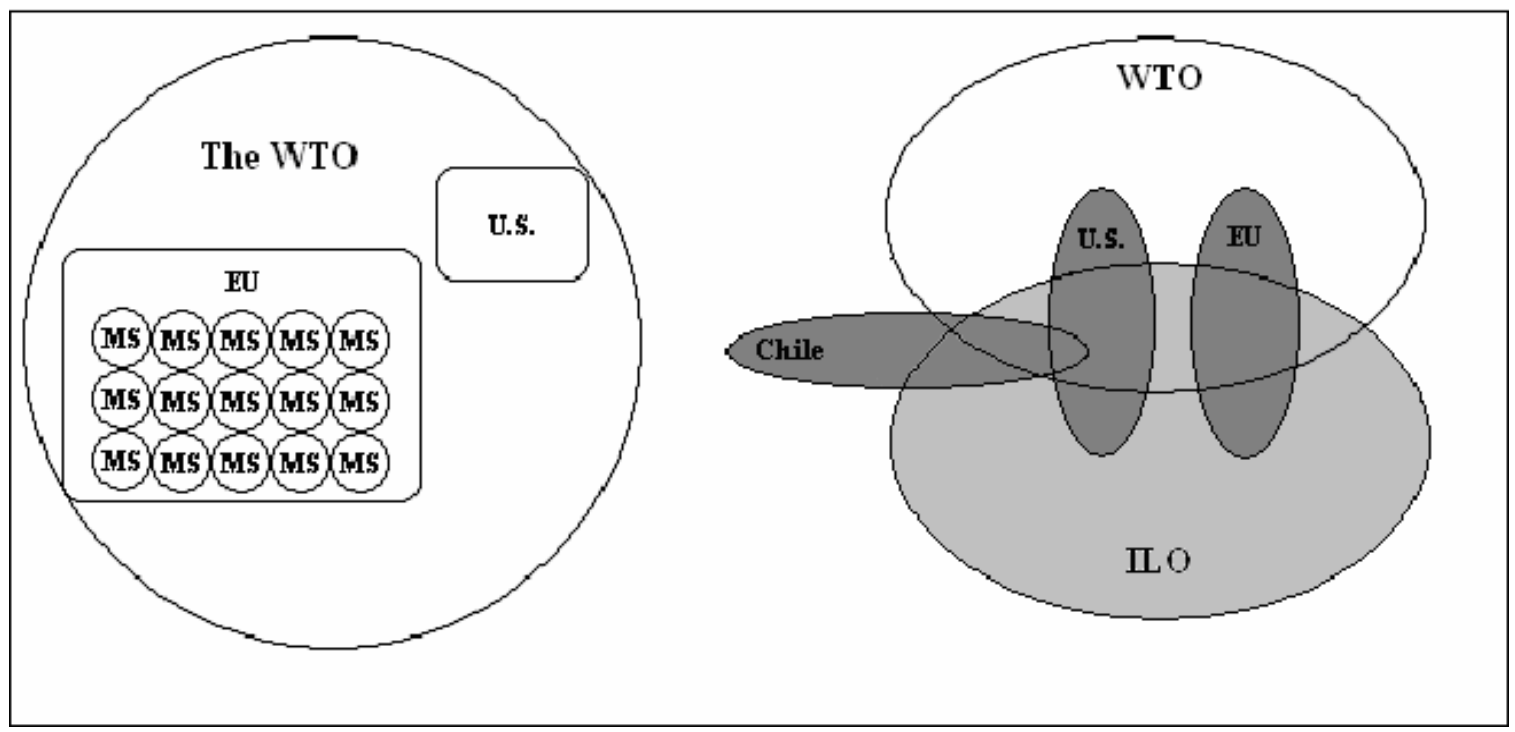


(MS=European Union Member State (15 before the latest enlargement))

Even though all nations in the world are increasingly entangled in multiple international commitments, the issue of institutional nesting has not yet been the object of many studies in political science. Some scholars analyze how different types of institutions (e.g. federal arrangements v. multi-level governance arrangements) have different politics (Hooghe and Marks, 2001:7, Shanks et al., 1996:, Tsebelis, 1990). Others analyze factors influencing what type of institutional forum is chosen (Abbott and Snidal, 2000:, Abbott and Snidal, 1998:, McCall Smith, 2000). Other scholars describe strategies to navigate or shift from one institutional forum to another (Abbott and Snidal, 2003:, Helfer, 2004), or the factors shaping whether new challenges are dealt with through existing institutions or generate new institutions (Aggarwal, 1998). These works focus on elements related to the politics of overlapping institutions. But they do not identify institutional nesting or overlap as a source of the specific politics they observe, or think about how nesting may matter beyond the specific question that they have defined.

The politics that nesting generates is as follows. At both the domestic and international levels, differentiation is the first approach used to resolve conflicts across rules—an attempt is made to define the realms separately to eliminate the conflict. When differentiation fails, hierarchy becomes necessary.

At the domestic level, the problem of nested institutions is usually solved through hierarchy, with a clear division of authority ensuring that different actors are supreme within their domain. For example, federalism involves working out the division of authority between 
federal, state, and local government, so that it is clear which actors have ultimate authority over a given policy issue. State and local politics often takes place in the shadow of federal politics, with all actors understanding that disgruntled groups may appeal to federal entities, and federal actors might invalidate state and local decisions or rule that state actors have final authority. The key difference between the domestic and international context is that the question of who has final authority and which rules trump is generally clearer or at least there is an established authoritative process to resolve any remaining ambiguities- an appeal to the courts.

Our argument is that at the international level the nesting of international institutions creates a problem of overlapping jurisdictions with no hierarchy to resolve conflicts across regimes. This problem is exacerbated when institutions not only overlap but are also nested one within another. At the international level it really is not clear who has the final authority to resolve conflicts across international agreements. The lack of hierarchy influences policy-making because negotiations take place with the realization that actors must obtain a waiver from the other institution or risk efforts within the overlapping or more encompassing institution to override the conflicting agreement. The fact of nesting/overlapping creates the opportunity for policy-entrepreneurs and interests groups to choose across political forums, picking the most authoritative forum willing to adopt their policy preference. Policy entrepreneurs will frame their issue to build political consensus within their chosen decision-making institution and to fit the style of the decision-making forum, with the policy outcome being a mixture of the preferences of the policy entrepreneurs and existing repertoire of policy formula within the decision-making regime. Those actors wanting a different policy may respond, however, by appealing to a different forum that has overlapping authority, seeking an authoritative decision that contradicts or undermines the policy of the other institution. Thus for forum shoppers, the nested context can 
generate a shifting "framing" of the issue depending on the forum in use (with different framings having substantive and political repercussions).

For decision-makers, the reality of forum shopping creates dilemmas: they try to avoid being gamed by forum shoppers, while keeping their options open by adopting strategies to maximize international bargaining leverage. Political decisions makers play across forums, creating a more complex two-level game that includes not only playing domestic actors off of international actors (Putnam, 1988), but also multi-lateral institutions off each other. Judicial decision-makers in a nested context may be invoked by forum shoppers to weigh in, but they face a real possibility that their sub-level policy decisions may be condemned, contradicted, or supplanted by the more encompassing institution. And the inherently fluid and political nature of international politics makes legal decision-makers far more hesitant to weigh in to resolve disputes about hierarchy. Thus the nested context in itself facilitates forum shopping and leads decision-makers, legal and political, to positions on international issues that are quite different from the "domestic" position they might advocate, when it is clear where final authority resides.

\section{Nesting/Overlapping at the Root of the Banana Dispute}

An illustration of the legal and political complexities triggered by the nesting and overlapping of international commitments is provided by the creation of the single European banana regime -at the root of the decade-long transatlantic dispute over bananas. Not only did nesting create the dispute in the first place, but it also delayed its resolution for over a decade. 


\section{The origins of the banana dispute}

The Treaty of Rome, which founded the European Economic Community (EEC) in 1957, called for the removal of all internal barriers to trade between its original six members as well as the introduction of a common external tariff applicable to imports from third countries in order for a true "common market” to exist. Despite of the Treaty’s ambitious goals, however, national markets long remained fragmented for a wide variety of goods. The 1986 Single European Act tried to remedy this fragmentation by calling for the completion of a true internal market in which goods, services, people and capital could move freely by the end of 1992.

Bananas were a good with a particularly fragmented market. Europe has never been a big producer of bananas, but it has long been a big consumer. Individual European countries imported bananas under an assortment of national practices, owing to preferences based on past imperial relationships and present vested interests (Sutton, 1997). By the time of the Single European Act, three distinct regimes existed for the import of bananas in Europe. First, France, Italy, the UK, Greece, Portugal and Spain offered tariff protection for producers either from the EEC or from the sixty-nine African-Caribbean-Pacific (ACP) countries, most of them former European colonies, benefiting from special trade agreements through the Lomé Convention. ${ }^{\text {i }}$ For instance, France got supplied bananas from its overseas departments of Guadeloupe and Martinique and from its former colonies, such as Côte d'Ivoire and Cameroon; Spain was supplied exclusively by domestic production in the Canary Islands. Under the Lomé IV Convention (1989-2000), bananas imported from the ACP entered the EEC duty free. A second regime governed the entry of bananas into Belgium, the Netherlands, Luxembourg, Denmark, and Ireland: a 20\% tariff on imports of bananas. Finally, Germany benefited from a special regime that guaranteed unimpeded, duty-free access to bananas from Central and Latin American 
in virtue of the "banana protocol" attached to the Treaty of Rome after fierce negotiations by then German Chancellor Konrad Adenauer(Rodden, 2001:72).

In order to comply with the requirements set forth in the Single European Act, Europe had to unify its multiple banana import practices into a single regime. But doing so entailed reconciling the apparently irreconcilable pulls of multiple institutions and treaty obligations in contradiction with one another (Lyons, 1994a). How could a new banana regime simultaneously: be consistent with the Single Market; honor its Lomé Convention commitment to protect the banana exports of ACP countries; honor the "Banana Protocol" in the Treaty of Rome guaranteeing Germany unimpeded access to bananas; and honor its obligations under the GATT to provide preferential access to imports from developing countries?

The European Commission first began to consider the banana issue in 1988 but only came to a conclusion in April 1992 after extensive negotiations and intense lobbying on the part of ACP Caribbean producers. The new regime, uniformly enforced throughout the European Community, established a multi-layered system of rules governing banana imports, giving a strong preference to EEC and ACP bananas, and discriminating against Latin American producers. The system was incredibly complex, requiring much administrative oversight, with several distinct categories for importing bananas. Supplies from the EEC (including overseas territories) were unrestricted; imports from the ACP countries were tariff-free up to 857,000 tons, after which they were subjected to a 750 ECU per ton tariff; and imports from other countries (mostly from Central and Latin American producers) were allotted a yearly quota of two million tons with a $20 \%$ tariff, and a $170 \%$ tariff beyond this quota. The Commission kept track of this regime by issuing import licenses that allocated quotas among banana distributors: two-thirds to traditional European and ACP importers, and one-third to other importers. 
The essential features of the new banana regime were adopted by a qualified majority vote in December 1992 . It was part of a package deal, and according to Oliver Cadot and Douglass Webber, it would never have passed were it not for the support garnered in trading across issues (Webber and Cadot, 2002:26). ${ }^{\text {ii }}$ The policy was opposed by Germany, Denmark, and Portugal. The hostile reaction led to the introduction of several changes when the Agricultural Council met to approve the new regulations in February 1993. These concessions were not enough for Germany who voted against it. Belgium and the Netherlands also voted against, breaking with precedent by reversing their previous position of support in December. But the regulation passed by receiving the support of Denmark, then EEC president. The single EEC-wide regime on banana imports (regulation 404/93) was implemented in July 1993.

The Complex Nesting of the Banana Dispute

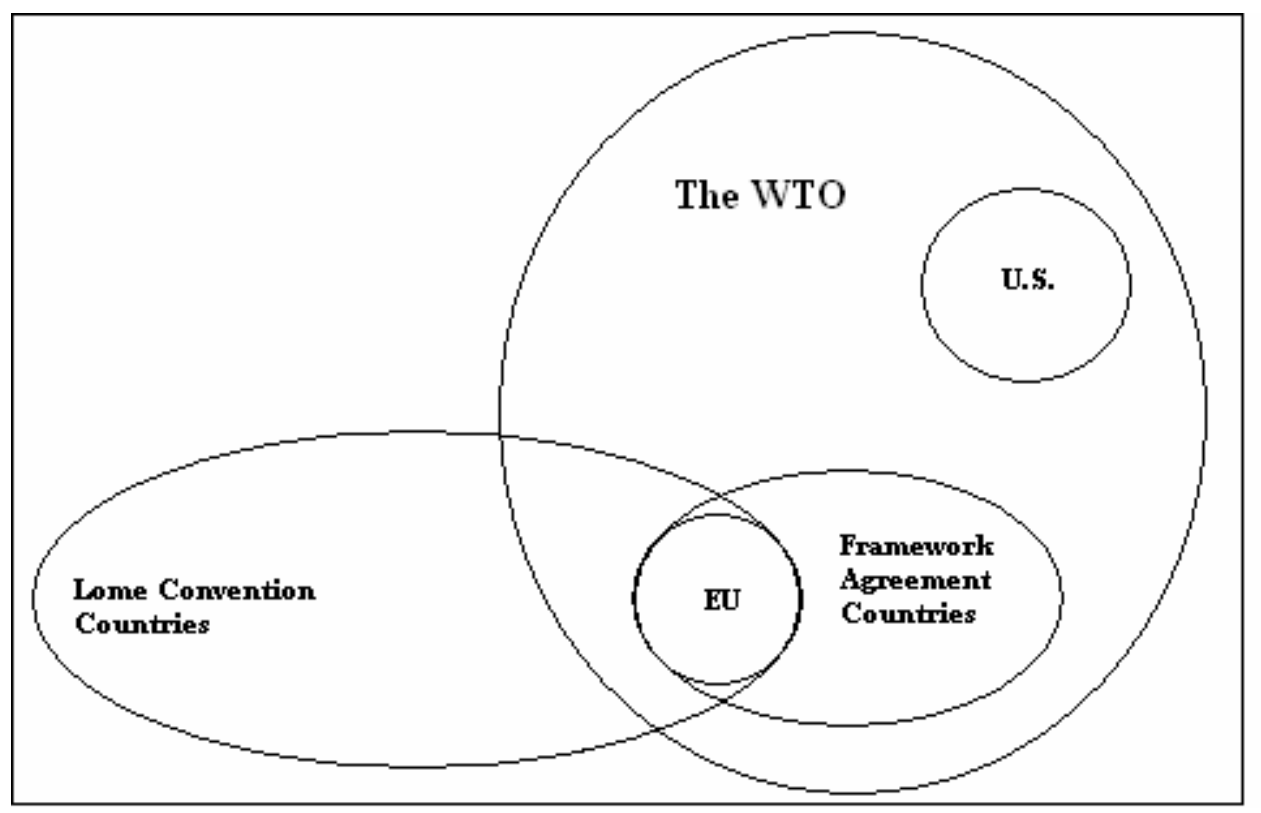

Not all Lomé countries are in the WTO, but all EU countries are in the Lomé Convention. The Framework agreement is between the EU and other GATT/WTO states. The US was not party to any of these agreements or conventions. 


\section{Resolving the Transatlantic Banana Dispute}

The EU's controversial policy ran afoul of WTO rules because it allowed for preferential access for some banana imports and not others. The nested nature of the member states within the EU, and of the EU within the WTO, provided multiple avenues banana producers and importers could use to challenge the contested policy. And the nested nature of the policy made the issue politically complicated for European legal and political decision-makers, who adopted convoluted positions quite different from what they would have chosen were they the final authority resolving the issue. All the layers of politics made finding a compromise much harder, allowing the relatively straightforward dispute to fester for ten years. We will analyze how nesting itself complicated the resolution of the dispute in Section III. The rest of this section identifies the various forms and loci of contestation in which the dispute over the EU-wide banana regime played out.

Europe's banana policy was contested in GATT while the new protocol was only under negotiation and not yet promulgated. In 1992, a group of Central and Latin American producers known as the “dollar zone” group-- Costa Rica, Colombia, Guatemala, Nicaragua and Venezuela.-- tried to put pressure on the European negotiation process by requesting the establishment of a panel to examine the consistency of the various European national banana regimes with GATT. In June 1993, the panel ruled in favor of the “dollar bananas.”iii The GATT consensus rule allowed the EU and ACP countries to block to ruling so that the panel report was never officially adopted by the Contracting Parties (Bessko, 1996:4). The panel ruling became moot when the national regimes were replaced with the unified Euro-wide banana regime, yet it was clear that remnants of national banana provisions that were GATT-illegal would remain GATT illegal. 
Once promulgated, the banana policy was immediately contested first from within the European Community (now the European Union (EU) as of 1993). The indirect beneficiaries of the new, convoluted arrangement were the member states with strong ties to the ACP countries. France supported the new regime above all because its “départements d'outre-mer”, especially Guadeloupe and Martinique, were banana producers. The UK also supported the regime because it offered protection to the Windward islands and preserved the interests of Geest, a major British agro-industrial company which provided shipping and support services for Windward bananas in Britain. By contrast, the member states who were forced to switch from low tariffs to the new EU system all lost from this arrangement.

Germany stood to lose the most. The world's highest per capita consumer of bananas, Germany imported 99.7\% of its bananas from "dollar zone” countries in $1991 .^{\text {iv }}$ Germany also had by far the lowest banana prices in Europe. ${ }^{\mathrm{V}}$ The new EU-wide banana regime forced Germany to import more EU and ACP bananas and to go from tariff-free Latin American imports to high-tariff dollar bananas. The net result was a 63\% increase in the price of bananas in 1994. This change hit Germans hard, especially given the special German fondness for bananas. As John Rodden explains, ever since the mid 1940s bananas have had a symbolic resonance of wealth and prosperity in both West and East Germany. When German Chancellor Konrad Adenauer had returned from his victorious negotiation resulting in a special "banana protocol" attached to the Treaty of Rome creating the European Community in 1957, he had brought a banana to the podium of the Bundestag and hailed the fruit for "represent[ing] the hope of many of us and a necessity for all of us!” that the days of past privation and humiliation were behind them. In Eastern Germany, political leaders had used bananas to "play Santa Claus of the nation” blessing the officially atheist Eastern Germany with a special December treat. When the Berlin 
wall fell, East Germans had embraced capitalist bananas, consuming twice as many bananas as Western Germans—-more than two per person per day(Rodden, 2001:72).

Once the German government had been outvoted on the European banana regime, it took the unusual step of airing internal EU dirty laundry by adding written reservation to the Uruguay Round accord, joined by Belgium, Denmark, Luxembourg and the Netherlands (Bessko, 1996:8). It then twice challenged the EU policy in front of the ECJ.vi Germany's first EC legal challenge, in May 1993, raised three arguments: the regulation violated fundamental rights granted by EU law; the regulation was not covered by the provisions of the Common Agricultural Policy (CAP); and the regulation violated GATT law. Belgium and the Netherlands joined the case in support of Germany. In its October 1994 opinion, ${ }^{\text {vii }}$ the ECJ rejected the German arguments, declaring that the Council of Ministers had not overstepped their powers in making the original decision to establish the regime and that the European judges did not have to take GATT provisions into consideration, except in special circumstances.

Challenges within the GATT/WTO continued as well. After the EU implemented its new banana regime, the "dollar bananas" producers asked for the establishment of another GATT panel. The January 1994 panel report concluded, once again, in favor of the plaintiffs, but the Europeans once again blocked the results of the "Bananas II" panel. Knowing that the new Uruguay Round agreement would make it impossible for the EU to block a WTO ruling, the EU offered a deal to the Latin American banana producers: if they were willing to forgo future action against the EU banana regime, they would get a higher quota for their banana exports to Europe, enjoy a lower tariff, and have a revised system of export licenses. In March 1994, four of these countries -Colombia, Costa Rica, Nicaragua and Venezuela—concluded a compromise, known as the "Framework Agreement" which, in exchange for waiving GATT action against the EU, 
raised the quota of banana imports and lowered the tariff (Lyons, 1994b:3) (Salas and Jackson, 2000:149). The agreement was concluded despite the protests of Guatemala, the United States, and Germany.

The Framework Agreement gave rise to the second German challenge in front of the ECJ. Even though the ECJ had refused to consider the compatibility of the banana regulation with the GATT, Germany nonetheless asked the European Court of Justice to rule on the Framework's Agreements compatibility with the rules of the WTO. The ECJ again refused to consider whether or not the regulation violated WTO rules. ${ }^{\text {viii }}$

Banana importers also took their dispute to national courts in Germany. German judges were concerned that the banana protocol might violate the German Constitution, and troubled by the ECJ's refusal to review the compatibility of the banana regulation with GATT requirements - after all European law and GATT law are equally binding within Germany. The German Constitutional Court appeared at first to be willing to consider that the regulation violated the German Constitution, allowing a lower court to consider if compensation was required for German importers. The Constitutional Court could have ruled that the European procedure of a direct appeal to the ECJ was the proper arena in which questions about compensation had to be handled. By allowing for a separate German review, the Constitutional court signaled that the highest German court was willing to allow German courts to be a rival forum to question the banana protocol. ${ }^{\text {ix }}$ With the Constitutional Court's encouragement, German courts repeatedly sent references to the ECJ asking the same questions their government had raised, and lost on (Alter, 2001:110-115). Eventually the German Courts backed away. The German Federal Fiscal court found that national courts lost their competence to interpret GATT law when the EEC became a de facto member of GATT in 1968 with the coming into force of 
the Common Customs Tariffs and Trade policy. ${ }^{\mathrm{x}}$ And the German Constitutional Court refused to consider whether or not the regulation violated the German Constitution arguing that so long as the ECJ is "generally" ensuring respect for the Constitution, it would not consider whether specific European policies violate specific provisions of the German Constitution. ${ }^{\mathrm{xi}}$

In the fall of 1995, the United States joined in on the complaint, which could now be brought under the brand new dispute settlement procedure of the recently created World Trade Organization (WTO). This American involvement resulted from the intense lobbying efforts of Chiquita, a US-owned company operating in Latin America, which had made extensive investments calculating on a liberalization of the banana market in Europe (Yes We Have No Profits, 2001). In September 1994, Chiquita Brands Inc. filed a Section 301 petition with the United States Trade Representative (USTR), claiming it was losing millions because of the new restrictive EU regime. Dole Foods and Del Monte, Chiquita's main competitors, did not join in the process, because they had less stakes in the matter as a result of different planning (Webber and Cadot, 2002). After intense lobbying by Chiquita, the USTR subsequently filed a request for the establishment of a WTO dispute settlement panel.

The US was joined as a complainant by Guatemala, Honduras, Mexico, and Ecuador (the world's largest producer of bananas, which had become a member of WTO in January 1996). They argued that the EU banana regime violated several of the trade agreements administered by the WTO, namely the General Agreement on Tariffs and Trade (GATT), the General Agreement on Trade in Services (GATS), and the Agreement on Import Licensing Procedures. The United States complaint focused not on the preferential access accorded the ACP countries but on the licensing arrangements and on preferential tariffs provided to the Latin American "framework countries" who had signed banana trade agreements with the EU (Hanrahan, 1999) 
The WTO handed out the "Bananas III” panel report in May 1997, which found, once again, against the European regime. While it found certain aspects of the EU banana regime to be inconsistent with WTO rules, it did not, however, find that the preferential tariffs accorded to the ACP countries were per se discriminatory because the EU had a special waiver for the Lomé Agreement. The panel's conclusions demanded the EU put its banana regime in conformity with WTO obligations. The EU appealed the panel's decision, but the WTO appellate body reaffirmed its decision in September 1997.

The EU implemented some changes to its regime, adjusting its import licensing system that had created a contested allocation of licenses, while retaining the quotas. ${ }^{\text {xii }}$ Nevertheless the USTR complained against the revised banana import regime. The WTO allowed the US to obtain compensation for lost banana sales in the form of punitive duties on American imports of EU products in retaliation. The US retaliated by imposing tariffs of $100 \%$ on $\$ 192$ million worth of EU imports into the US (none of which are agricultural products). The US chose to exempt the Netherlands and Denmark from the increased tariffs, "in recognition of their voting record against the adoption of the new banana regime,” keeping the political pressure on Germany. ${ }^{\text {xiii }}$

The banana dispute was finally resolved in April 2001. The EU agreed to implement a new regime based on a tariff-only system by 2006, after a transitory period during which bananas are imported into the EU through licenses distributed on the basis of past trade. The agreement took effect in July 2001, at which time the United States suspended the retaliatory sanctions it had imposed on EU imports in 1999. 


\section{Unpeeling the Layers: Nesting/Overlapping and the Banana Dispute}

In a world of independent decisions and non-nested regimes, the conflict over bananas makes little sense. The sums involved —at least for the US and Europe--were very small, whereas the protracted dispute was expensive. The EU banana regime was costly for European banana consumers, cumbersome for European importers, and very disadvantageous importers lacking favorable import quotas. When the US retaliated by imposing tariffs on goods unrelated to bananas, additional costs were created for European exporters of these goods --from bed linens to coffee-makers.

The new WTO dispute resolution system also suffered non-negligible legitimacy costs. This conflict was one of the first test cases of the new multilateral trade rules, and by most accounts it was a real failure. The new WTO system had made it practically impossible to block panel rulings, yet Europe still refused to change its policy even in the face of negative legal rulings and retaliation. Europe's intransigence was evidence of the weakness and unfairness of the WTO system where the powerful could ignore WTO rulings and buy their way out of compliance, while poorer countries were constrained by retaliation to comply (Alter, 2003:787). Meanwhile the banana and almost concomitant beef hormones rulings infuriated many in Europe, and gave fodder to the nascent anti-globalization groups, which saw these rulings as an unacceptable intrusion on national sovereignty in the name of protecting American corporate interests (Gordon and Meunier, 2001). For many activists, a ruling by an unelected multinational body that the United States could punish Europe because it chose to import its bananas from poor former colonies (who seemingly had nothing else to export, short of turning to drug production) was an example of corporate power and economic liberalization run amok. These arguments culminated in November 1999 where anti-globalization activists, some of them dressed as 
bananas, contributed to the derailment of the launching of the new millennium round of multilateral trade negotiations in Seattle, the first one undertaken under the new WTO.

This section uses counterfactual analysis to explore how the politics regarding bananas would have been different if a layer of the nesting --EU, Lomé, WTO-- were removed. In thinking about what each layer added, we gain insight into the politics that the nesting of the dispute generated. Of course counterfactual analysis always involves speculation, but it allows us to at least consider the possibility that the costly choices made at various points in the dispute were the result of the nesting/overlapping of institutions.

\section{Scenario 1: No European Union regime}

The revamping of the EU banana policies and the creation of a single EU-wide banana regime were part of the drive to complete the internal market. Without supranational EU politics at play, the original practices would likely have continued: countries with historic ties to ACP countries would have continued to apply tariffs to non-ACP bananas as historic agreements allowed, other European countries would have continued with their uniform $20 \%$ tariff, and Germany would have kept its own policy of duty-free banana imports. Thus, one concrete effect of the EU's existence was a change in German, Benelux, Danish and Irish policy that probably would not have occurred otherwise. The first GATT Banana ruling had only condemned the French, Italian, Portuguese, Spanish, and UK discriminatory tariff, and that was before the Lomé waiver. With the WTO Lomé waiver, the unharmonized GATT banana regime would not have violated any WTO rules.

The drive to complete the common market created pressure to harmonize the EU banana policy—but such pressure does not dictate how harmonization had to occur. The justification for 
the banana regime was that supporting ACP banana production was part of Europe's development aid policy. If the only issue were aiding ACP countries, a far more efficient solution would have been direct aid from Europe to Lomé countries. ${ }^{\text {xiv }}$ Cadot and Weber hypothesize that the EU could have accomplished its aid to ACP countries by levying a $17 \%$ tariff on dollar bananas, distributing the proceeds to ACP countries. Because the EU had a WTO waiver for the Lomé convention, such a tariff would have been WTO legal. Instead, the EU crafted and then defended its banana policy, with a complex quota system that turned out to be extremely complicated for importers to navigate. The system created inequalities among importers and required large amounts of administrative resources to administer and adjudicate. Furthermore the quota system created a vested group of favored importers who fought against any change in the rules. Given all of the political, legal and administrative costs associated with the quota system, why choose the quota system? Internal EU politics made the particular form of harmonization, despite its many drawbacks, nonetheless desirable. The main disadvantage of the tariff system compared to the quota system was that EU budget rules do not allow for the earmarking of tariff revenue (Webber and Cadot, 2002:10)_probably because if the EU could earmark tariff revenue, it would generate an incentive to protect. Because tariffs revenues could not be earmarked, choosing direct aid would have meant consuming part of the EU budget for foreign aid. Perhaps even worse, a seventeen percent across the board tariff on dollar bananas would have meant eliminating the total ban on banana imports in France and Spain. Dollar banana access to these markets would have caused pressure on the few French and Spanish banana producers located in France’s Dom Tom territories and in Spain’s islands. This pressure would have come at a time when finance ministers were committed to trimming the Common Agricultural Policy's budget and thus when price pressure on domestic EU bananas was very unwelcome. The EU ended up giving subsidies to local banana producers, but at the time the 
single EU banana regime was debated, negotiators thought that the subsidies would have been bigger without the system to boost the price of bananas overall, and that the Framework agreement would help Europe avoid any WTO costs for its policy. Indeed perhaps the chief attraction of the Banana regulation was that it generated no budgetary costs—no immediate foreign aid requirement and no immediate subsidy requirement-while satisfying those ACP and European banana importers seeking rents.

The existence of the EU layer also explains the legal and political imbroglio in which Germany found itself. If there were no EU level of policy-making, we would have expected Germany not to abide by the conditions of the single banana regime since German importers and consumers were the hardest hit by the changes. Past import levels were determinant in setting up import quotas for the new system. Having focused on Latin American bananas for so long, German importers lacked long-standing import relationships with ACP exporters, and thus they were disadvantaged by the EU system for allocating quotas. The distress of German importers was real enough to encourage lower German courts to order an injunction in the application of the EU banana regime, and to repeatedly ask the European Court of Justice and the German Constitutional Court to (re)consider whether or not the EU banana regime was legal, and whether it undermined the basic rights of importers by denying them their ability to exist as commercial enterprises. ${ }^{\mathrm{xv}}$ Without Germany's overall commitment to the EU, we might have expected Germany to choose defection, and thus to refuse to enforce the quota regime. With the EU, it appears that Germany accepted a deal for Bavarian farmers in exchange for the banana regime (Webber and Cadot, 2002:26).

Finally, the move towards the single European market and the consolidation of European integration were also a central reason for the crucial involvement of the United States in the 
dispute. Chiquita had bet that the Single European Act would lead to a free market throughout Europe and had invested heavily in banana plantations in Latin America and in shipping equipment in the years prior to the creation of the EU-wide banana regime. When the EU finally adopted its banana regime, Chiquita was in a real bind. With excess capacity and huge debt, in a very real and personal way the fortunes of Chiquita's CEO became tied to the policy the EU adopted. This explains why Chiquita gave expensive political donations to both the Republican and Democratic political parties, and extensively lobbied congress to become involved in the dispute while its competitors Dole and Del Monte stayed out of the case. This desperate strategy was an attempt to save the job, company, and personal fortunes of Chiquita's CEO(2001).. ${ }^{\text {xvi }}$

\section{Scenario 2: No Lomé regime}

To have created a harmonized system for bananas that did not include tariff-free access for ACP bananas and higher tariffs for dollar bananas would have meant violating the Lomé Convention's promise of preferential access to the European market for bananas. Having tarifffree bananas for all would not have been sufficient, since ACP bananas were more expensive to produce than Latin American bananas -for reasons having to do with poor soil and terrain, adverse climatic conditions, and low vertical integration of the production process.

The issue was only in part a conflicting European Treaty obligation. The Lomé conventions were themselves a means to deal with a deep cleavage within the EC. France, and then later the UK and Spain, were especially committed to helping their former colonies through a preferential trade system. The fight over bananas in the 1950s was largely about whether other European member states would help pay to help current and former colonies. The absence of a coordinated banana regime for so many years was a symptom of the deeper antipathy towards 
supporting former colonies among European states without colonies. The Lomé conventions represent a brilliant packaging of member states wanting to aid former colonies with member states wanting to help some of the poorest countries in the world. Europe could boast that the Lomé conventions represented the largest financial and political framework to facilitate NorthSouth cooperation, and to aid some of the poorest countries in the world.

But in writing into the Lomé convention a very specific promise of preferential access for ACP bananas, the old cleavage was brought back into the fore. Jonathan Rodden summarized the unsaid sentiment "The EU "banana split”...exposed the sharp political tensions underlying the move toward a single borderless European Market. The new EU import regulations aimed to help banana growers in European tropical islands (e.g. France's Martinique and Guadeloupe, Spain's Canary Island) and in former European colonies in Africa, the Caribbean, and the Pacific. Germany, which lost all of its own colonies after World War I balked: Why should its own interests be sacrificed to those of France and Spain, whose banana growing former island colonies have been the beneficiary of the 1993 (policy)" (Rodden, 2001:69) Even worse, the new policy came at the direct cost to importers and consumers of dollar bananas.

Giving preference to very poor countries was, in itself, not the problem. A special GATT waiver for the convention was granted in October 1994, and was slated to last until the end of Lomé IV (2000). When the waiver was set to expire, 56 ACP countries members of the WTO threatened to oppose new trade negotiations on non-related issues --such as environment, labor, and the "Singapore issues" of investment and competition policy—in the upcoming Doha round of multilateral trade negotiations unless the waiver was extended. In 2001, the WTO again allowed a waiver to the EU to give preferential access to ACP imports until 2008, under the new Cotonou agreements that had replaced the Lomé convention. In other words, the Lomé 
convention had become the focal point around which to organize developing country interests. The nesting of Lomé countries within WTO helped them leverage their political power. The EU could not play a two level game telling the Lomé countries that the WTO prohibited the policy, because these countries could play the WTO game to get a waiver, and the EU political game to pressure European countries to maintain their advantaged market access.

\section{Scenario 3: No WTO regime}

Without a formal WTO dispute resolution system, there would have been no new legal challenge to the EU banana regime, no finding of non-compliance, and no retaliation. The WTO system mostly differs from its predecessor, the GATT dispute resolution system, in the inability of states to block adoption of adverse panel decisions and the added layer of an appellate process. Under the old GATT system, Europe actually did block the dispute resolution panel report, even though its banana import practices had been found illegal, thus it prevented the potential imposition of multilaterally-approved retaliatory sanctions. The creation of the WTO led to an immediate, though still unsatisfactory from the perspective of the US and Ecuador, change in EU behavior. In anticipation of a challenge to the banana regime under the new WTO system, the EU offered a deal to the Latin American countries that were parties to the GATT case: according to the 1994 "Framework Agreement", the EU would raise the global quota to 100,000 tons and reallocate unused import licenses, in exchange for the "Framework countries" (signatories to the agreement) dropping their claims to future GATT cases. Latin American countries started to disagree amongst themselves over the allocation of the quota within their group, leading the EU to drop its offer of a deal and to then block the panel report. But soon 
after, Colombia, Costa Rica, Nicaragua and Venezuela accepted a reduction in the EU tariff and an increase in their tariff quota to 2.2 million tons, leading to an arrangement that was similar to the status quo ante of the old EU banana regime. In exchange, these countries promised not to challenge the banana regime for the life of the regime, which was slated to expire in December 2000 (Sutton, 1997). This was exactly what was supposed to happen-the new enforceability of WTO law was expected to encourage settlements in the direction of greater compliance with the law. (Ecuador, which was not a member of GATT at the time, was not part of this arrangement, nor was the US.)

Moreover, without the WTO layer, it is unlikely that the US would have been involved at all in the dispute. While the US would still have the section 301 system, it is not clear that the EU would be in violation of any trade agreement vis-à-vis the U.S. And since the problem was an EU policy towards third countries, it is doubtful that the US would have pressed the case under section 301 -especially in the absence of a means to enforce compliance.

The existence of the WTO explains why the US spearheaded the campaign against the EU banana regime. After all, the US is not a significant producer of bananas, ${ }^{\text {xvii }}$ and it had not been a party to the original dispute when five Latin American banana producers raised the first case in GATT. Interagency divisions preceded the U.S. filing of the case in the WTO, with the State Department not keen on pressing the matter given its low salience and potential for disruption of the transatlantic relationship. But Chiquita lobbied Congressmen who in turn put pressure on the United States Trade Representative (USTR)—an executive agency that serves at the pleasure and behest of Congress. Because of the corporate interests of Chiquita and its strong lobbying power, the USTR put its negotiators under considerable pressure to pursue aggressively the banana case in the WTO (Webber and Cadot, 2002:, Hanrahan, 1999). ${ }^{\text {xviii }}$ 
Once the case was underway, the banana dispute became the focal point of the free trade vs. Fortress Europe debate, as well as the first test case of how the new dispute settlement mechanism was going to work. Many US interest groups were concerned not only about bananas but also about the precedents that might be established in the banana case. Was the EU employing dilatory tactics to postpone or even evade implementing decisions by the WTO's Dispute Settlement Body that went against domestic political interests? One could see the WTO as having exacerbated the conflict by brining in the US and upsetting the diplomatic compromise in place. But in some ways bananas was a perfect case to test the new WTO system precisely because few American and European interests were directly at stake, thus the protracted dispute could test the system while generating less domestic political pressure. While the domestic pressure was less intense, there was much interest in this case as a harbinger of what might come if the issues of beef hormones and genetically modified foods were litigated.

Because of the precedential value of the case, more interests besides banana producers became interested and saw themselves as having a stake in the case. Their interest did not per se tilt in the direction of free trade over protection, shifting the balance of power of free traders. The quota system and the framework agreements were themselves an expensive payoff scheme. Preferential import quotas were the equivalent of cash in the pocket of importers-they could buy dollar bananas at a low price, and pocket the profit reaped by selling these bananas on the price-inflated European market. Since many of the banana importers were owned by banana companies, the profits went into the pocket of the banana producers. When Latin American countries protested the EU banana regime in the GATT system, because the WTO’s compulsory jurisdiction system was coming, the EU responded by increasing the preferential quotas of Latin American producers-which was akin to direct compensation for countries hurt by their policy. 
Of course European consumers paid for this arrangement. But let us not pretend that the WTO system is all for the benefit of consumers. Trade agreements are hard driven bargains. The WTO is not designed to not eliminate bargaining for the benefit of the consumer. Rather it is designed to regulate the bargaining environment so as to decrease power advantages in bilateral bargaining while hopefully locking in advances in free trade reached through bargaining. Consumers may benefit from this free trade, but the main objective is to avoid a beggar-thyneighbor spiral of competitive tariffs like happened prior to World War II.

On the one hand, the WTO layer "resolved" the dispute. The threat of WTO litigation led the EU to offer the "framework agreement" to Latin dollar producers, and to ultimately change its quota system of import license allocation. On the other hand, the WTO layer exacerbated the conflict by turning it into a transatlantic battle and, ironically, by creating the incentives for political bargaining where the general public seems to be the greatest loser. The public loses twice from the dispute settlement—bananas are more expensive in Europe than they would otherwise be, and banana importers get to extract rents instead of either the EU or the ACP banana producers collecting tariff revenue to distribute. Indeed in some respects, more layers means more actors that have to be bought off and compensated. Even if the EU really does convert the system to a tariff based system with a lower tariff for ACP bananas and an across the board tariff for dollar bananas, banana consumers will continue to pay "rents" thus one can question how much the WTO has led to a more free-trade oriented system, or shifted the balance of power in favor of free traders over protectionist interests. 


\section{Conclusion}

The banana dispute was the first transatlantic dispute to be adjudicated under the newly created WTO. As such, it helped define the politics of the new WTO system and created a precedent for dealing with a lack of a hierarchy of norms in the post-Cold War era. This complicated case is an example of the new trade politics-multilayered, multi-venued, with provisions imbricated within and across multiple international agreements. As the number of international commitments proliferates, the nesting and overlapping of institutional regimes will become increasingly prevalent. How will this shape international politics? Can we derive any insights from the banana case that can be generalized to future conflicts created by nested/overlapping international regimes?

George Tsebelis reasoned from theory that "seemingly suboptimal choices indicate the presence of nested games" (Tsebelis, 1990:248). We show specifically how nesting contributed to the choices made. The banana dispute represents in many respects a "typically" complicated example of the consequences of institutional nesting/overlapping in the international realm. The dispute was created by nesting, since the completion of the single European market produced a clash between the EU obligations vis-à-vis its former colonies through the Lomé Convention and its obligations as a member of the multilateral GATT/WTO trading system. The different layers of nesting help us understand the seemingly puzzling behaviors in the dispute- the adoption and then defense of the convoluted quota system, and the strategies of political and legal actors within the dispute.

Given the inherently nested nature of the EU, in which every deal represents a complex bargain among states and European institutions made in the shadow of the WTO, we can expect 
trade related EU policy to be byzantine and complicated to decipher. This study suggests that the problem isn't so much the technocratic nature of Eurocrats as much as it is the nested international nature of the EU where majority voting or decision-making by the party in power is just not how decisions are made.

Within the EU there is a clear legal hierarchy of rules. Without the EU there is not. We argue that what made the issue of nesting/overlapping institutions so controversial and difficult to resolve was the absence of clear hierarchy between all the layers involved -European member states, the EU, the Lomé countries, and WTO. Legally and politically, the relationship of EU law to WTO law is ambiguous. EU member states have accepted unitary EU representation within the WTO, yet they still retain their individual memberships (Meunier and Nicolaidis, 1999). A decision could have been made to replace member state participation with EU participation, but because the issue of the Commission's authority over trade in services was contentious, such a decision was never made (Bourgeois, 2000:73). Thus the problem of whether a state is obligated to the EU agreement over the WTO agreement (or vice versa) was left unresolved by political bodies. This ambiguity allowed for the internal opposition to the protocol to be exploited in European member state's national courts, and to bubble over into the Uruguay Round negotiations.

This ambiguity also makes it hard for the ECJ to answer the question of whether WTO obligations are legally supreme to EU law. One the one hand, the ECJ's refusal to review the compatibility of EU law with WTO law is legally remarkable in that the hallmark of the legal method is the like application of reason and rules across cases. Yet here we find the ECJ refusing to do exactly what it asked national courts to do-enforce international rules at homeand we even find ECJ interpreting similarly worded texts differently based on the political 
context (Bourgeois, 2000). Typically the question of the relationship between international and domestic law is a matter for the domestic polity to resolve. Thus the legal ambiguity on these issues is hardly unique to the EU. Nor is the solution chosen unique to the EU. Pretty much all domestic courts avoid "tying the hands" of governments, forcing them to comply with international agreements when other executive branches are not similarly bound. We find that vis-à-vis WTO law, the ECJ acts like a supreme court nested in the international order. It tries when possible to interpret EU law consistently with WTO law. When the Council explicitly invokes international legal obligations or makes clear that the EU law is intended to bring the EU into compliance with an international obligation, the ECJ acts as the Council's enforcer, making sure that EU law and member state law complies with international legal obligations. But it leaves any decision about whether or not the EU should comply as a political decision for political bodies to decide in the first place.

With the ECJ position now clearly defined, European domestic actors may decide it is not worth trying to challenge common policies in European Courts on the basis of conflicts with international treaties. The national judicial positions are likely hold as long as the issue is in the realm of a complicated political bargains among competing interests. It is hard to imagine that the German Constitutional Court would be willing to ignore a serious violation of its constitution simply because the ECJ appears to "generally" respect the rights of European citizens.

Thus one generalizable finding from this study is to expect to find contortions and inconsistencies when actors that enforce hierarchy in the domestic realm are confronted with issues related to the international realm. This finding is significant because a number of scholars place their hope for international law in domestic courts who can become enforcers of international rules at home (Hathaway, 2004:, Slaughter, 2004). This study suggests that the goal 
of domestically enforced international law may remain elusive unless political actors declare some hierarchy among the conflicting obligations they create.

How political contortions ultimately influence the politics of international policy-making and international politics itself is not entirely clear. In the banana dispute, the legal inconsistencies between European law and the WTO agreement led to a policy to buy off those most hurt through the quota system. The winners under the quota system (Lomé countries and importers) then fought hard for maintaining the system as is, and they continue to prefer quotas over a tariff system in which the revenues accrue to the EU rather than the holders of preferential import licenses or Lomé countries. Because of the difficulties of changing the nested policy, the number of actors needed to be bought off expanded-making the policy more costly than necessary if the goal was simply to aid Lomé countries.

The banana dispute was a specific dispute about a specific policy, and in many respects it was an "old style" trade dispute about straight up protection as opposed to a disagreement over values and priorities. Still Lomé countries pressed their case through opposition to the unrelated "Singapore issues” of investment and competition policy, Caribbean countries (unsuccessfully) lobbied the US to drop its banana case during the 1994 Summit of the Americas, and anger over the banana and beef hormones cases contributed to the EU's decision to pick up again its challenge to the US export subsidy regime (the FSC case)--so banana politics did spill into other international arenas. For WTO disputes over beef with hormones and genetically modified crops, the likelihood of political spillover is even greater because these disputes touch on the delicate issue of how regulators deal with scientific uncertainty, an issue that is relevant in environment food safety, and nuclear technology politics. Because there is no clear hierarchy of international agreements, a legal victory or loss in one venue is highly likely stir politics in another venue to 
try to undercut the authority of the any one settlement. Raustiala and Victor's discussion of the "regime complex" seems to exemplify such politics, showing a rush of actors and countries to use different forums to create different sources of authority for their preferred policy. Raustiala and Victor hypothesize a spread of "regime complexes," and the politics such complexes engender. Our study reinforces this finding by suggesting that the absence of hierarchy itself be an intentional strategy which drives a demand for international agreements that enshrine different perspectives on hotly contested issues (Raustiala and Victor, 2004).

A final question worthy of further investigation is under what conditions do nesting and overlapping create conflict? In a way, the banana dispute may be a unique case. The multiple layers of international commitments not only created the conflict, but also made it much harder to resolve. Yet, with maybe the exception of international disputes on hormones and biosafety, most other nested issues in world politics do not explode. Understanding why in some cases the dog barks and in others it does not might be useful to prevent the emergence of other protracted, potentially costly inter-institutional conflicts.

(2001) Yes, We have no Profits Fortune, 144, 182-196.

Abbott, K. and Snidal, D. (1998) Why States Act through Formal International Organizations Journal of Conflict Resolution, 42, 3-32.

Abbott, K. and Snidal, D. (2000) Hard and Soft Law in International Governance International Organization, 54, 421-456.

Abbott, K. and Snidal, D. (2003) In The Impact of International Law on International Cooperation(Eds, Benvenisti, E. and Hirsch, M.) Cambridge University Press, Cambridge.

Aggarwal, V. K. (1998) Institutional Designs for a Complex World: Bargaining, Linkages and Nesting, Cornell University Press, Ithaca.

Alter, K. J. (2001) Establishing the Supremacy of European Law: The Making of an International Rule of Law in Europe, Oxford University Press, Oxford.

Alter, K. J. (2003) Resolving or Exacerbating Disputes? The WTO's New Dispute Resolution System International Affairs, 79, 783-800. 
Bessko, Z. (1996) Going Bananas over EEC Preferences? A Look at the Banana Trade War and the WTO's Understanding on Rules and Procedures Governing the Settlement of Disputes Case Western Reserve Journal of International Law, 28, 265.

Bourgeois, J. H. J. (2000) In The EU, the WTO and the NAFTA: Towards a Common Law of Trade(Ed, Weiler, J. H. H.) Oxford University Press, Oxford, pp. 71-123.

Gordon, P. H. and Meunier, S. (2001) The French challenge : adapting to globalization, Brookings Institution Press, Washington, D.C.

Hanrahan, C. (1999) The US-European Union Banana Dispute. CRS Report RS20130.

Hathaway, O. (2004) Between Power and Principle: A Political Theory of International Law Manuscript in Progress...

Helfer, L. (2004) Regime Shifting: The TRIPS Agreement and New Dynamics of International Intellectual Property Making The Yale Journal of International Law, 29, 1-81.

Hooghe, L. and Marks, G. (2001) Multi-level governance and European integration, Rowman \& Littlefield Publishers, Lanham, MD.

Lyons (1994a).

Lyons, R. (1994b) "European Union Banana Controversy Florida Journal of International Law, 9, 165-188.

McCall Smith, J. (2000) The Politics of Dispute Settlement Design International Organization, 54, 137-180.

Meunier, S. and Nicolaidis, K. (1999) Who Speaks for Europe? The Delegation of Trade Authority in the European Union Journal of Common Market Studies, 37, 477-501.

Putnam, R. (1988) Diplomacy and Domestic Politics; the Logic of Two Level Games International Organization, 42, 427-460.

Raustiala, K. and Victor, D. (2004) The Regime Complex for Plant Genetic Resources International Organization, 58, 277-309.

Rodden, J. (2001) German Banana Republic? Culture and Society, 38, 68-74.

Salas, M. and Jackson, J. H. (2000) Procedural Overview of the WTO EC-Banana Dispute Mauricio Salas and John H. Jackson, 2000, "Procedural Overview of the WTO ECBanana Dispute", Journal of International Economic Law, March 2000, Vol. 3, No. 1, pp. 145-166., 3, 145-166.

Shanks, C., Jacobson, H. K. and Kaplan, J. H. (1996) Inertia and change in the constellation of international governmental organizations, 1981-1992 International Organization, 50, 593-627.

Slaughter, A.-M. (2004) A New World Order, Princeton University Press, Princeton.

Sutton, P. (1997) The Banana Regime of the European Union, the Caribbean, and Latin America Journal of Inter-American Studies and World Affairs, 39, 5-36.

Tsebelis, G. (1990) Nested games : rational choice in comparative politics, University of California Press, Berkeley.

Webber, D. and Cadot, O. (2002) Banana Splits: Policy Process, Particularistic Interests, Political Capture, and Money in Transatlantic Trade Politics Business and Politics, 4, 109.

\footnotetext{
i The Lomé Convention, initially signed in 1975 after the accession of Great Britain into the EEC (and renewed in 1979, 1984 and 1989), is the world's largest financial and political framework for North-South cooperation. This special relationship between the EEC and the ACP countries is characterized by non-
} 
reciprocal trade benefits for ACP states including unlimited entry to the EC market for 99 per cent of industrial goods and many other products. Of the 69 ACP countries, at least 8 are significant banana producers. Lomé Conventions: OJ 1976, L25/1; OJ 1980, L347/1; OJ 1986 L 86/1; OJ 1991, L 229/I.

${ }^{\text {ii }}$ Cadot and Webber discuss extensively the politics of the voting on this issue Webber, D. and Cadot, O. (2002) Banana Splits: Policy Process, Particularistic Interests, Political Capture, and Money in Transatlantic Trade Politics Business and Politics, 4, 109. See also Sutton, 1997, p. 14.

iii Latin American bananas are often referred to as “dollar bananas” because they are grown by American multinationals like Chiquita and Dole on huge, efficient plantations in Latin America.

${ }^{\text {iv }}$ With $14.9 \mathrm{~kg} / \mathrm{capita}$ compared to an average EU consumption of $9.3 \mathrm{~kg} / \mathrm{capita}$ Bessko, Z. (1996) Going Bananas over EEC Preferences? A Look at the Banana Trade War and the WTO's Understanding on Rules and Procedures Governing the Settlement of Disputes Case Western Reserve Journal of International Law, 28, 265..

${ }^{\mathrm{v}}$ In 1992, bananas cost \$1.3/kg in Germany, vs. \$2.07 in the UK. Sutton, P. (1997) The Banana Regime of the European Union, the Caribbean, and Latin America Journal of Inter-American Studies and World Affairs, 39, 5-36.

${ }^{v i}$ Germany v. Council, ECJ C-280/93 [1994] ECR I-4973. See: para 78. In a second case, the German Government challenged the Commission's system for implementing the disputed regulation, but the ECJ dismissed this case on a technicality. Opinion 3/94 [1995] ECR I-4577.

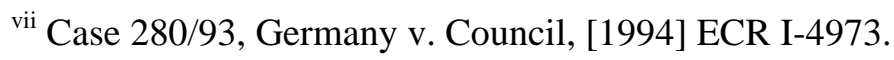

viii The ECJ ruled that it did not need to review the compatability of the Framework agreement with WTO law because the Framework agreement had come into force with the Uruguay round, and thus any assessment as to the agreements legality raised under EEC Article 228 would be legally moot. Opinion 3/94 on the Framework Agreement on Banans, decision of 13 December 1995 [1995] ECR I-4577.

${ }^{\text {ix }}$ Firma T. Port v. Hauptzollamt Hamburg-Jonas. (T. Port I, Banana I) BVerfG decisions of 25 January 1995. First Chamber of the Second Senate 2 BvR 2689/94 and 2 BvR 52/95, [1995] EuZW 126. Verwaltungsgerichtshof Hessen decision of 9 February 1995, [1995] EuZW 222.

x 1996 judgment of the German Federal Fiscal Court Europaische Zeitschrift fur Wirtschaftsrecht (EuZW) 126-128, cited in Gerard G. Sander, 1998 The EC Banana Regime - a Testcase for the Relationship between WTO, Regional and National Law. ${ }^{x i}$ Firma T. Port v. Hauptzollamt Hamburg-Jonas. (T. Port II) FG Hamburg order 19 May 1995 [1995] EuZW 413. BFH decision 22 August 1995. T. Port II, Second banana 
ruling) BVerfG decisions of 26 April 1995. First Chamber of the Second Senate 2 BvR 760/95, [1995] EuZW 412.

xii The banana quota available to Latin American countries continued at 2.2 million metric tons at a tariff of 75 ECU per ton (one ECU, or European Currency Unit, is equal to \$0.92). In addition, the EU established another quota of 353,000 tons to take into account consumption of Latin American bananas in Austria, Finland and Sweden, countries that joined the EU in 1995. The EU abolished the import licensing system and replaced it with one it says is WTO-compatible. The EU changes took effect on January 1, 1999 Hanrahan, C. (1999) The US-European Union Banana Dispute. CRS Report RS20130. xiii USTR Charlene Barchefsky, quoted in "USTR announces list of European products subject to increased tariffs". Document 98-113, Office of the USTR.

xiv The EU claimed that aiding the banana industry was preferable to providing direct aid. Caribbean bananas are grown on small, family-run farms, and bananas seem to be the only year-round crop that can recover quickly enough after storm or flood damages. Moreover, according to the defenders of the EU regime, the only alternative crop for these countries in the absence of markets for their banana exports would be drugs. Perhaps. But drug production is also a problem in Latin America, and Europe is also vulnerable to the effects of drug production in Latin America. Also, a straight up tariff on dollar bananas might have provided a sufficient benefit for ACP producers.

${ }^{x v}$ Firma T. Port v. Hauptzollamt Hamburg-Jonas. BVerfG decisions of 25 January 1995. First Chamber of the Second Senate 2 BvR 2689/94 and 2 BvR 52/95, [1995] EuZW 126. Firma T. Port v. Hauptzollamt Hamburg-Jonas Verwaltungsgerichtshof Hessen decision of 9 February 1995, [1995] EuZW 222. Discussed in Alter, K. J. (2001) Establishing the Supremacy of European Law: The Making of an International Rule of Law in Europe, Oxford University Press, Oxford.

${ }^{\text {xvi }}$ Based on interviews with the CEO of Chiquita who took over after Chiquita filed for Chapter 11 bankruptcy.

xvii Hawaii produces bananas for domestic consumption. It was argued that by diminishing consumption for dollar bananas in Europe, the price of Hawaiian bananas could be adversely affected. This may be true, but most commentators explain US actions by focusing on Chiquita banana's considerable efforts to lobby Congress rather than the Hawaiian banana industry.

${ }^{\text {xviii }}$ Not everyone in Congress agreed with the policy promoted by Chiquita and a number of Congressmen wanted to avoid creating a damaging precedent. Members of the congressional African-American Caucus expressed the view that abruptly ending the EU preferences to ACP countries or modifying them substantially would result in significant losses in export earnings and would therefore have major economic, political and social consequences for ACP countries. Indeed, in the $106^{\text {th }}$ Congress, a bill (H.R. 1361) was introduced to bar the US from retaliating against the EU in the advent of its failure to comply 
with the WTO's decision. Pleas and pressure to drop the case also came from many leaders of Caribbean nations assembled in the 1994 Summit of the Americas. Overall, however, the US administration accepted the arguments in favor of pursuing the case. 